\title{
Trial Sets Value
}

National Cancer Institute

\section{Source}

National Cancer Institute. Trial Sets Value. NCI Thesaurus. Code C117466.

A factor assigned to a trial set boundary. 